\title{
Conflict as a possible catalyst for democratic relations in the work of the Family Health team
}

\author{
O conflito como possível catalisador de relações democráticas \\ no trabalho da equipe de Saúde da Família \\ El conflicto como posible catalizador de relaciones democráticas \\ en el trabajo del equipo de Salud de la Familia
}

How to cite this article:

Silva IS, Arantes CIS, Fortuna CM. Conflict as a possible catalyst for democratic relations in the work of the Family Health team. Rev Esc Enferm USP. 2019;53:e03455. DOI: http://dx.doi.org/10.1590/S1980-220X2018003403455

Iramildes Souza Silva ${ }^{1}$

Cássia Irene Spinelli Arantes ${ }^{1}$

Cinira Magali Fortuna²

${ }^{1}$ Universidade Federal de São Carlos, Programa de Pós-Graduação em Enfermagem, São Carlos, SP, Brazil.

${ }^{2}$ Universidade de São Paulo, Escola de Enfermagem de Ribeirão Preto, Departamento Materno Infantil e Saúde Pública, Ribeirão Preto, SP, Brazil.

\begin{abstract}
Objective: To analyze conflict situations in the basic care team as possible catalysts of democratic relations at work, favoring team performance. Method: A qualitative study with a family health team from a municipality in the interior of São Paulo State. The data collected included systematic observation and interviews with workers who were organized and analyzed from the confrontation with the theoretical reference of the health work process. Thematic content analysis was used. Results: 16 workers participated. The data are organized into two thematic categories: the reception of unity as a place where conflicts become more explicit, and the conflict as an opening for building democratic relationships in teamwork. Conclusion: Receiving users at the reception and who will or will not work in this space reveals different values and conceptions about the care each professional provides, and constitutes a situation that generates conflict. However, opposing ideas in the conflict are fruitful because they are able to complement each other and provide a qualitative leap in team relations, with a tendency to influence a reduction in the vulnerabilities of the relations between the subjects. This is a pressing and current need in the discussion involving the reorganization of health practices.
\end{abstract}

DESCRIPTORS

Patient Care Team; Family Health; Conflict (Psychology); Interpersonal Relationships; Interprofessional Relations.
Corresponding author:

Iramildes Souza Silva

Av. Irmã Antônia de Arruda Camargo,

249, Jardim Vale das Rosas

CEP 14806-033 - Araraquara, SP, Brazil

iramildessouza@hotmail.com
Received: 02/23/2018

Approved: 09/25/2018 


\section{INTRODUCTION}

The proposal to expand the care capacity of health care services in the context of the Family Health Strategy (FHS) relies on the work of the multidisciplinary team ${ }^{(1)}$. It is considered that this way of operating health work would bring satisfaction to both workers and users, because it enables the former to have a support network and knowledge sharing, and to the latter a diversity of shared and unique therapeutic actions.

To this end, the National Humanization Policy ${ }^{(2)}$ also proposes teamwork as a possibility to create services which better suit the needs of workers and users.

Teamwork is something harmonious in the collective imagination of workers, managers and users, and not considered as procedural or dynamic, which excludes conflict. It is common to hear expressions that erase the existing differences in working relationships, such as: speaking the same language, having the same goals, being a family, and/ or getting along with everyone.

In this article we consider that the work process of the teams in action is crossed by different noises, among them the inequality existing among the hierarchical professional categories $^{(3)}$, despite there being a discourse of horizontality.

Such noise refers to the technical and social division of the work present in the teams, in which some works, particularly intellectual ones, are valued more in every way, including salary, social recognition and power; elements which can act as precursors of conflict. In addition to these, conflict can originate from relationships with people who have different values, beliefs, training and goals ${ }^{(4)}$.

"Conflict is permeated by social interaction, which manifests itself in the context of services, conditioned by the way the work is organized. Therefore, it is not the general and subjective human relations that are in conflict, but those which conform to the concreteness of the interactions that happen in the work process"(5).

Conflict has been seen as a harmful phenomenon to organizations for a long time, and should be avoided or extirpated, and in the present has been fundamental for the growth and development of those involved when well-managed, particularly in health ${ }^{(6)}$.

Conflict can enable change and redefine action strategies which favor individual and collective empowerment and the strengthening of relationships. However, if not properly administered, it can trigger an irrational escalation of other conflicts, negatively impacting the quality of services offered in health ${ }^{(7)}$.

Thus, the guiding questions of this text were: how does conflict arise for primary care professionals? Is there potential in it for teamwork?

The objective of this study is to analyze the conflict in the primary care team as a possible catalyst for democratic work relations, favoring teamwork.

\section{METHOD}

\section{STUdY TYPE}

This is a descriptive and exploratory study with a qualitative approach, anchored in the theoretical framework on the health work process ${ }^{(8)}$, which considers the historicity, sociality and directionality of work present in the worker's mind as a crucial element for transforming work and those who perform it.

\section{SCENARIO}

This research was developed with 16 employees of a Family Health $(\mathrm{FH})$ team in a municipality in the state of São Paulo, which has $24 \mathrm{FH}$ teams in its Basic Health Network, 10 teams working in conventional basic units and a Support Nucleus $(N A S F)$. The criterion for choosing the team considered the joint action time of the workers in the same space for more than 1 year.

A systematic observation was conducted guided by a basic script focusing on team interactions, totaling approximately 40 hours. The information was recorded in a field diary (FD), then the semi-structured interview was carried out with the FH staff: a nurse, a physician, five community health agents, three nursing technicians, an administrative agent, two dentists, two oral health aides $\approx(\mathrm{OHA})$ and one health territory manager (HTM).

\section{Data collection}

Data collection took place between the months of September and October 2012. The interview script was guided by issues that addressed the relationships among workers. The interviews lasted on average 50 minutes each, were recorded in audio and transcribed in full, preserving the anonymity of the participants.

\section{DATA ANALYSIS AND PROCESSING}

The data were treated using the content analysis method with thematic categorical analysis technique.

The analysis was based on comparing the data with the theoretical framework of the health work process ${ }^{(8)}$. The data were organized after transcribing the interviews and diary entries into themes which grouped similar ideas in response to the objective.

\section{ETHICAL ASPECTS}

The research project was approved by the Ethics and Research Committee with Human Beings of the Universidade Federal de São Carlos, under number $72132 / 2012$.

The Informed Consent Form was explained to the participants, who then accepted it and signed it, thereby agreeing to participate in the study, in compliance with CNS Resolution 466/12 of the National Health Council. Participants in the study were identified through the initial letter of the professional category to which the interviewee belongs or the function they exercise by the following abbreviations: Nurse (N); Nursing technician (NT); Doctor (Doc); Dentist (D) and Community Health Agent (CHA). Ordinal numerals were added following the sequence of interviews in professional categories where there was more than one worker. 


\section{RESULTS}

Sixteen (16) workers participated in the study. The results show that work as a process is operated and operates on relationships established as social relations, embraced by a diversity of actors with different purposes which favors conflict, an element which has its matrices in power relations. Two thematic categories were constituted for the data analysis: the reception of the unit as a place where conflicts become more explicit, and the conflict as an opening for building democratic relations in teamwork.

\section{THE RECEPTION OF THE UNIT AS A PLACE WHERE CONFLICTS BECOME MORE EXPLICIT}

The way the health service is organized to serve the population receives importance in this category, which points to the reception of the unit as a triggering factor of conflicting situations in the daily lives of the workers of this team:

There was no professional at the reception many times. There was always an appeal among the members so that one of them stayed at the reception (FD).

The nurse told the territory manager that the reception situation has been a problem for the team and that was reflecting badly throughout the service. Of the total of four meetings observed by the researcher, the reception was pointed out by the team as a critical node to be solved in three of them (FD).

The task reception is pointed out as overload for the team, in such a way that some claim to neglect their action nucleus by occupying most of their time in the reception:

I have my things to do as a nurse, I can't stay at the reception, I don't think it's my job $(\mathrm{N})$.

And the visits, how can I do them if I have to stay at the reception? (CHA 2).

The loss of a common medical record available in the physical space of the reception involved all the professionals and resulted in a conflict that affected all of the team:

You've seen the arguments we have because of the reception, for having "deleted" a patient record scheduled for today, so the whole team was mobilized to find it ... if there was someone in charge of the reception, this wouldn't have happened (...) we wouldn't be so tired and stressed (NT 2).

The reception is indicated as a stage of the work process capable of greatly influencing the following processes, being able to determine the outcome of the service rendered to those who attend the unit:

The reception is abandoned (...) if I arrive in a place and don't have a reception to welcome me, the rest doesn't matter $(\mathrm{N})$.

Everything that happens at the reception desk spills over the whole day. (NT3).

Spontaneous demand appears as a challenge for the team as a way to organize the service:

I've already said in a meeting that the team needs to adjust the agenda, it's two o'clock in the afternoon and reception is still occurring at the counter. We have to educate the population (...) otherwise we can't win (HTM).

Based on the following testimony, staying at the reception represents the worker's exposure to situations which are not always known, nor always possible to answer. In addition, it is the location of the unit that presents a high degree of complexity, requiring the team to undertake large efforts:

I think they (CHA) have a hard time staying at the reception, they are insecure $(\mathrm{N})$.

After I took the introductory course (...) I find myself more prepared to deal with the complaints that arrive at the front (CHA 3).

It seems that from the understanding of this worker, the reception space is not up to the knowledge level conferred to a graduate professional, and thus becomes a less prestigious place from the perspective of knowledge and power:

I don't see staying in the reception as a position of discredit (...), but I fear that staying there could mean that dental care is less important for the team than the reception, I fear that this will diminish the importance of my work (D2).

\section{CONFLICT AS AN OPENING FOR BUILDING DEMOCRATIC RELATIONSHIIPS IN TEAMWORK}

The data analysis led to the idea that the conflict in the encounter between the workers of the team appears as a living expression of their relations, and it is necessary to recognize its existence:

Regarding the team it's that business, it is dealing with buman beings (...) because where there are discussions/arguments, it flows, but where this doesn't happen, where everyone only hugs and kisses, there aren't good results (NT 1).

The conflict can be considered as an element that produces more democratic relations of power, and can open space for workers' demonstrations:

(...) so it is a fight for space, for opinions, but everything contributes (...) and people "get caught" here, but (things) move (N).

There has to be conflict because not everytbing I say and hear is true. We argue, question (...) every day we sit down to solve the issues (...), to study cases (NT 1).

The absence of a physical-biological complaint brought by the CHA is not understood by the team as a health need, and this gives rise to conflicts, since it demands recognition of their work:

Many times I don't have the same point of view as the professional who's here in the unit. I try to show bim the other side (...) I feel like an important piece (...) although sometimes it's kind of difficult, but we worry about looking at it from the community side (CHA 5).

We "butt heads" with the team, but it works (CHA 2).

The dance project (...) I fought so much for it, I cried for it! I lost so many hours. I lost no, I won (...) I see teenagers dancing today. They are on the way that I want them to be (CHA 1).

The conflict is designed as a possibility of exercising freedom, and the worker can choose to make it latent or want to solve it:

There are days that we leave sad, crying and hurt, then another 
has passed, we go home, think, evaluate. One day I was wrong, the next I was right, if I had to put in an agenda at the meeting the other day (...) it is not with so much anger, without so much conflict, even with the people, mental conflict, when we return there is already another conception, or apologize, and dialogue occurs $(\mathrm{N})$.

(...) if you have a relationship conflict, for example, we already put it on the table, fight, argue, leave with an upset expression, but the next day we know that this agenda has already been resolved, it doesn't let us createlspread gossip (NT3).

When I'm convinced that what I'm doing is right, then I fight, (...) we debate with the unit's coordinator (NT2).

The conflicts which are presented can lead to a proposal of a productive character, in which there are no winners or losers, and the space of the team meeting gains importance in this production.

There was a strange situation between a nurse and me (...) I didn't like it, but instead of taking it away, we had a meeting, and I explained. I spoke and she spoke too, the situation was made right and got better, everything went well (NT 2).

Yesterday a CHA rudely answered me. Today at the meeting I explained the situation, understood and it was over (...) here we don't leave things like this "on the table", we go and solve them $(\mathrm{N})$.

According to what the worker brings, just as conflict situations arise from different places or sources, the responses to resolve things can also arise from the different people involved. It is mentioned that all indistinctly possess (in a certain way) a condition for propositions toward understanding:

People are free to express themselves (...) this already creates some conflicting situations, in which you'll have to create some way out to lessen this conflict. This is interesting in the team, sometimes this attitude is not part of the graduates, but part of the CHA. You imagine that the bargaining power is in the graduate (Doc).

I'm not afraid to do my job, even if I have to confront someone and "butt heads", as I've done many times, to defend health issues from families and patients, I've stuck my neck out (...) and things were resolved (CHA 4).

Work overload was linked to one of the causes of team conflict:

We don't have an adequate staff (...) at the moment I think it's very conflicting. You've seen the discussions/arguments we're having, the technician is tired, the other is tired $(\mathrm{N})$.

On the other hand, the redistribution of roles among its members, aiming at co-responsibility, emerged as a way to solve conflicts:

Teamwork is sharing. We've discussed this and done this in the team (...). Each strives to do some things beyond their own assignments: one checks the telephone bill, another the stock and other vaccine things, another makes referrals for colposcopy (...). In addition to performing my production, I also control weekly epidemiological surveillance and monthly material re- quirements (Doc).

If each one is to argue: - "Ah, this is not my job" (...) there really isn't teamwork, because you have to extrapolate your tasks a little (D1).

Each one doing a little does not overload or stress the team (HTM).

\section{DISCUSSION}

The data show that workers experience conflicts in the daily lives of professional practices and that they find ways to confront them, such as letting the "heat" of the annoyance pass and bring them into the team meeting. The vision about what the care should be, the priority cases and the types of activities to be offered make the team "butt heads" sometimes, or lead to understanding.

The fact that the reception is a point of conflict which still does not appear as something to be problematized by the staff is noteworthy. It reveals itself as a triggering site for conflicts in the stages of the team's work process, which tend to affect health care production. It is there that the users present themselves spontaneously, without a scheduled appointment, and where they should be welcomed and receive a response to their demand.

By delegating this work to only a few workers and assigning a lower value to this function, the health team blames the population who is not "educated" to come at pre-established times and has its members wanting to escape from that space.

The unit's reception is understood herein as the initial reception of the user in the service, which appears in the results, associated with situations generating discomfort and as a confrontation point between the work team.

This function is a privileged place, because it expresses the differences about what, when and how a person should be served when attending the health service. Thus, it allows production and visibility of different positions in the team marked by the intention of each worker based on the institutional plan and mainly on their freedom of action.

It was evidenced that when the demands presented at the reception differ from the rules established by the service (user arrival time to be attended to and absence of prior scheduling, for example), the worker has to use their freedom to think about other choices, and conflicts are established.

Something which goes beyond what is planned seems like something difficult to solve for the reception worker. In this case, working at the front desk reception may correspond to dealing with strangeness, reservations, and resulting in a sense of helplessness, fear, and conflict in the team's work.

It may be pertinent to say that the reception in this investigation presents itself as the expression locus of the tension between supply and demand that surrounds the agenda models and the spontaneous demand that knocks at the door of unity. It is noticed that there is a mismatch between the real need felt by the user and the programmed model for the service, greatly impacting the way the team operates and signifies their work, fueling the conflict. 
"Reception tensions may be higher depending on the expectations of the population regarding the demand for health care. Considering that legally there is a firm commitment to offer services by the unit, which surpasses the role of provider, the first negative relational impact can jeopardize the work development of the group of professionals. Thus, reception as a reorganization of the service includes the proper functioning of reception as an effective communication channel" ${ }^{\prime 9)}$.

Among other aspects, it is also worth discussing who is assigned to receive the user at the family health unit (FHU), which was revealed in this study as being a problem situation for the team. At the same time that the reception is considered strategically capable of determining the other processes in the service, it is also presented as a less valued role in the perspective of knowledge and power, because little visibility is conferred to whomever makes first contact with the user.

The unequal way in which the various workers are socially inserted in the work process stages, and in this case in the unit's reception, was evidenced considering that the professionals from the university level claim their more nuclear positions, with allegations in this paper to the extent of that which is proper to their doing and their knowledge would suffer losses, thereby being the cause of recurrent conflicts. In this case, there also seems to be an apparent zeal to protect the profession, thus establishing a power relationship.

In Foucauldian studies, knowledge and power are interwoven in such a way that knowledge can be manipulated to exercise power, but it is only through regulated and institutionalized truth that a relationship of power is established. There is no power relationship without the constitution of a field of knowledge, nor in knowing that it does not presuppose and does not constitute power relations ${ }^{(10)}$.

It is in this aspect of power relations that the reception presented little prospect in interpreting the statements. It seems that the reception does not abstract the technological apparatus figured in the biomedical model, adhering recognition (especially social), making it deferred in relation to the other activities.

A study related to the types of conflicts between primary care workers indicates that "although the work and of all those involved are necessary and important in the health unit, there is conflict resulting from disrespect arising from asymmetrical relationships and unequal social recognition between categories"(5).

According to reports from this study, staying at the reception could also mean subjecting oneself to oppressions produced by the need for satisfactory responses from the point of view of those who attend the service. The denial of this could lead to hostility and disrespect towards those involved.

"Humanization and comprehensiveness guidelines precisely point to the challenge of dealing with oppressions which, consciously or not and voluntarily or not, produce disrespect and non-recognition. However, it is pointed out that oppression contains the germ of struggle and it is driven by the normative principle of self-realization, which connects with ethics, making experienced conflicts in health spaces favorable to the reconstructive efforts of humanization and comprehensiveness in the health field"(11).

It is also emphasized that the statements led to interpreting that the reception is linked to the work process stage that can express concern of how much the health service is committed or not to the people's access. This proposition allows us to look at this first contact with the service as a moment which is rich in possibilities for breaking hegemonies such as rigid knowledge hierarchization, which constitute barriers to access.

In relation to the category involving conflict as an opening for building democratic relations in teamwork, we sought to look at the results in order to understand how the team articulates itself to solve the conflicts that are produced in providing care from a perspective of health care, where care management tends to happen in a more participatory way among the subjects in action. In this scenario, it was agreed that conflict has constructive value; it can act as escape lines for new ways of producing work ${ }^{(12)}$.

The testimonies and interpretation of the data express that when the conflict is "worked on", it can be an agent of more horizontal relations of power, considering that it can open space for manifesting ways of thinking care, regardless of the study degrees that the professionals hold and/or the positions they hold. The example of this is the movements of resistance evidenced by the CHA when they fight in searching for legitimacy of tools which they consider pertinent to their work process, with a view to recognition.

"The absence of this recognition constitutes the motivational basis of the conflict, which should not be only understood as an operative participant in power relations, but demands for reciprocal recognition are implied in its occurrence, be it in the sphere of primary interpersonal relations, legal relations or social esteem"(5).

"The experience and expression of conflicts and disputes of various orders are intrinsic to this need for recognition and enables affirming that the teams have a space of struggle in this sense. However, it is acknowledged that the constant experience of the struggle for recognition can be profoundly destabilizing for the team, thus rendering work capacity unfeasible"(13).

The study points out that conflict constitutes a barrier to realizing trust, bonding, mutual respect and recognizing the work of the other, constituting elements which make up teamwork ${ }^{(14)}$.

In contrast, the analysis in this research leads to understanding a movement by workers of different categories, who took the conflict as a strategy to overcome the obstacles encountered and as a way to re-signify the work.

This movement is not done with all the encountered problems, for example in this investigation the way of operating the reception, while generating conflicts, has not yet gained the strength to re-signify work and relations.

Another cause of conflict in the team figured in the work overload, which as reported led the team to reorganize their work process so that each assumed roles even until being under the responsibility of others. 
This sharing is usually conceived, however it is not always easy for the teams, considering that it requires a movement from the knowledge of each profession to others, towards work management ${ }^{(15)}$, which demands flexibility in interactions.

Is the overload of some workers more expressed and valued than others? Would not the reception also be overworked? When discussed, these issues could assist the team in its task of caring for people in a given territory.

Based on the data, the idea of the power of interdisciplinary work for reinventing new forms of action is based on the recognition of the team that there are escapes for destabilizing established values, which sometimes obstruct performance and alienate the worker. It is not a question of denying overload as one of the most influential factors in the difficult task of the teams, but of seeing how they find solutions to their difficulties, which in this particular instance is in the ways of the conflict resulting from reorganizing the work process.

In the studied FHS, overload seems to be related to performing the activities predicted in the model which includes a vast menu to be offered. The implications of this reality are countless compared to what is idealized. "A shared project which requires the management of different knowledge is defended, guided by ethical values which guide collective choices, but are hardly conflict-free"(16).

It is analyzed herein that conflict is mostly inevitable and necessary to create an environment in which people feel free to disagree with one another. It is easier for workers to develop mutual trust if they believe that they can counteract and that they will not be isolated or harmed because they have different perspectives ${ }^{(17)}$.

In this investigation, the team meeting proved to be an important strategy for exposing discrepancies, seeking solutions to existing conflicts, and a worker's participation tool in the decision-making processes in the day-to-day work of the FHS. It was observed that some problems gained visibility and different analyzes in the meetings, backed up by a recovery of the experiences and knowledge of the workers, which led to the contradictions present in their daily work when confronted face-to-face.

Thus, there is a possibility of disruption in the movements provided by the conflict, since workers can be encouraged to expose their opinions and consequent discomforts by opening up in the attempt to uncover what is throbbing in their minds, sometimes obstructing their creativity and desire to do the work. Thus, spaces for expressing individual freedoms are opened up as an essay of horizontal relations between workers.

This is the power placed in the conflict, being of progressively deconstructing vertical relations of power $^{(3)}$ and collectively building autonomies through the $\mathrm{FH}$ team based on new ways of relating, and involving the multiprofessional team. The interdependence between those involved is also highlighted, and it is expected that this will have an important consequence in the dynamics between them.
Each action in health work is intertwined with another, and interdependence, in that sense, could function as a source of conflict ${ }^{(18)}$.

It should be pointed out that defensive postures, characteristic of the traditional approach to conflicts, must be objects of recognition and confrontation, since these two issues have been neglected in the health area, hindering a culture of developing a problem solving process and preserving a culture of peace ${ }^{(18)}$.

After all, since conflict is an unavoidable phenomenon, it is imperative to understand and discern its origins to administer it assertively, suppressing its dysfunctionalities and potentializing its productive effects. Conflict management does not necessarily imply in their solution, sometimes it means constructively stimulating them for team learning.

Thus "conflicts must be examined and worked on as an important raw material for managing and building new pacts, which would temporarily respond better to the different interests at stake"(19).

\section{CONCLUSION}

This study shows points of conflict between workers in the FHS. The reception of users at the reception area and who will or will not work in this space reveal different values and conceptions about the health concept and the care provided by each professional.

Although these questions regarding reception were not problematized, there was fluency by the team in facing the opportunity to discuss conflicting situations, with the aim of finding solutions to the difficulties that present themselves. In this direction, the team meeting proved to be a privileged space, and the conflict in this area would act as a driving force in this process.

Therefore, the existence of escape routes in the FHS registered in the form of conflicts are considered in this study, which can promote a transposition of hierarchical lines, favoring more assertive responses in health from the perspective of the relations established in the work in team.

It has also been shown that opposing ideas in a conflict are fruitful because they are able to complement each other and provide a qualitative leap in team relations, with a tendency to influence a reduction of vulnerabilities in the relations between the subjects. This is a pressing and current need that cannot be dispensed with when the discussion involves the reorganization of health practices.

As limitations of this study, the impossibility of achieving generalizations is highlighted, since it analyzed situations involving conflict between workers of only one family health team. It is advisable that other studies with different contexts and teams be carried out in an attempt to understand other aspects related to conflict, how they both negatively and positively interfere in care production, as well as implementing other theoretical and methodological references which subsidize greater exploitation of this issue. 
RESUMO

Objetivo: Analisar as situações de conflito na equipe de atenção básica como possível catalisadoras de relações democráticas no trabalho, favorecendo a atuação em equipe. Método: Estudo qualitativo com equipe de saúde da família de um município do interior paulista. Os dados coletados incluíram observação sistemática e entrevista com trabalhadores que foram organizados e analisados a partir da confrontação com o referencial teórico do processo de trabalho em saúde. Utilizou-se da análise de conteúdo temática. Resultados: Participaram 16 trabalhadores. Os dados estão organizados em duas categorias temáticas: A recepção da unidade como local onde os conflitos ficam mais explícitos e $\mathrm{O}$ conflito como abertura para construção de relações democráticas no trabalho de equipe. Conclusão: O recebimento dos usuários na recepção e quem vai ou não trabalhar nesse espaço revelam valores e concepções diferentes sobre o cuidado de cada profissional, situação que gera conflito. No entanto, ideias antagônicas situadas no conflito são fecundas por serem capazes de se complementarem e propiciarem um salto qualitativo nas relações da equipe, com tendência a influenciar a diminuição das vulnerabilidades das relações entre os sujeitos. Essa é uma necessidade premente e atual na discussão envolvendo a reorganização das práticas em saúde.

\section{DESCRITORES}

Equipe de Assistência ao Paciente; Saúde da Família; Conflito (Psicologia); Relações Interpessoais; Relações Interprofissionais.

\section{RESUMEN}

Objetivo: Analizar las situaciones de conflicto en el equipo de atención básica como posible catalizadoras de relaciones democráticas en el trabajo, favoreciendo la actuación en equipo. Método: Estudio cualitativo con equipo de salud de la familia de un municipio del interior del Estado de São Paulo. Los datos recogidos incluyeron observación sistemática y entrevista con trabajadores que fueron organizados y analizados mediante la confrontación con el marco de referencia teórico del proceso laboral en salud. Se utilizó el análisis de contenido temático. Resultados: Participaron 16 trabajadores. Los datos están organizados en dos categorías temáticas: La recepción de la unidad como sitio donde los conflictos resultan explícitos y El conflicto como apertura para construcción de relaciones democráticas en el trabajo de equipo. Conclusión: El recibimiento a los usuarios en la recepción y quienes van o no van a trabajar en dicho espacio revelan valores y concepciones diferentes sobre el cuidado de cada profesional, situación que genera conflicto. Sin embargo, ideas antagónicas ubicadas en el conflicto son fecundas por ser capaces de completarse y facilitar un salto cualitativo en las relaciones del equipo, con tendencia a influenciar la disminución de las vulnerabilidades de las relaciones entre los sujetos. Esa es una necesidad apremiante y actual en la discusión involucrando la reorganización de las prácticas sanitarias.

\section{DESCRIPTORES}

Grupo de Atención al Paciente; Salud de la Familia; Conflicto (Psicología); Relaciones Interpersonales; Relaciones Interprofisionales.

\section{REFERENCES}

1. Brasil. Ministério da Saúde; Secretaria de Atenção à Saúde, Departamento de Atenção Básica. PNAB - Política Nacional de Atenção Básica [Internet]. Brasília; 2017 [citado 2018 maio 28]. Disponível em: http://bvsms.saude.gov.br/bvs/saudelegis/gm/2017/prt2436_22_09_2017. html

2. Brasil. Ministério da Saúde; Secretaria de Atenção à Saúde. Política Nacional de Humanização da Atenção e Gestão do SUS. Gestão Participativa e Cogestão [Internet]. Brasília; 2009 [citado 2018, maio 9]. Disponível em: http://bvsms.saude.gov.br/bvs/publicacoes/ gestao_participativa_cogestao.pdf

3. Silva IS, Arantes CIS. Power relations in the family health team: focus on nursing. Rev Bras Enferm [Internet]. 2017 [cited 2018 Feb 11];70(3):58087. Available from: http://www.scielo.br/scielo.php?script=sci_arttext\&pid=S0034-71672017000300580

4. Lima SBS, Rabenschlag LA, Tonini TFF, Menezes FL. Lampert AN. Conflitos gerenciais e estratégias de resolução pelos enfermeiros gerentes. Rev Enferm UFSM [Internet]. 2014 [citado 2018 fev. 23];4(2):419-28. Disponível em: https://periodicos.ufsm.br/reufsm/article/ view/11888/pdf

5. Carvalho BG, Peduzzi M, Ayres JRC. Concepções e tipologia de conflitos entre trabalhadores e gerentes no contexto da atenção básica no Sistema Único de Saúde (SUS). Cad Saúde Pública [Internet]. 2014 [citado 2018 fev. 23];30(7):1453-62. Disponível em: http://www. scielo.br/pdf/csp/v30n7/0102-311X-csp-30-7-1453.pdf

6. Torres CS, Cunha P. Gestão de conflitos em uma organização da área da saúde em Portugal Ciênc Cognição [Internet]. 2014 [citado 2018 fev. 23];19(3):384-92. Disponível em: http://www.cienciasecognicao.org/revista/index.php/cec/article/view/946/pdf_29

7. Claro RFS, Cunha PFSS. Estratégias de gestão construtiva de conflitos: uma perspetiva dos profissionais de saúde. Psic Saúde Doenças [Internet]. 2017 [citado 2018 fev. 23];18(1):55-68. Disponível em: http://www.scielo.mec.pt/pdf/psd/v18n1/v18n1a05.pdf

8. Mendes-Gonçalves RB. Tecnologia e organização social das práticas de saúde: características tecnológicas do processo de trabalho em saúde na Rede Estadual de Centros de Saúde de São Paulo. São Paulo: Hucitec; 1994.

9. Guerrero P, Mello ALSF, Andrade SR, Erdmann AL. User embracement as a good practice in primary health care. Texto Contexto Enferm [Internet]. 2013 [cited 2018 Feb 11];22(1):132-40. Available from: http://www.scielo.br/pdf/tce/v22n1/16.pdf

10. Foucault M. Vigiar e punir: nascimento da prisão. $41^{\text {a }}$ ed. Petrópolis: Vozes; 2013.

11. Wernet M, Mello DF, Ayres JRCM. Recognition in Axel Honneth: contributions to research in health care. Texto Contexto Enferm [Internet]. 2017 [cited 2018 Feb 13];26(4):e0550017. Available from: http://www.scielo.br/pdf/tce/v26n4/en_0104-0707-tce-26-04-e0550017.pdf

12. Deleuze G, Parnet C. Diálogos. São Paulo: Escuta; 1998.

13. Miranda L, Rivera FJU, Artmann E. Trabalho em equipe interdisciplinar de saúde como um espaço de reconhecimento: contribuições da teoria de Axel Honneth. Physis [Internet]. 2012 [citado 2018 ago. 28];22(4):1563-83. Disponível em: http://www.scielo.br/pdf/physis/ v22n4/a16v22n4.pdf

14. Souza GC, Peduzzi M, Silva JAM, Carvalho BG. Teamwork in nursing: restricted to nursing professionals or an interprofessional collaboration? Rev Esc Enferm USP. 2016;50(4):640-47. DOI: http://dx.doi.org/10.1590/S0080-623420160000500015 
15. Campos GWS. Saúde pública e saúde coletiva: campo e núcleo de saberes e práticas [debate]. Ciênc Saúde Coletiva [Internet]. 2000 [citado 2018 maio 26];5(2):219-30. Disponível em: http://www.scielo.br/pdf/csc/v5n2/7093.pdf

16. Nunes EFPA, Carvalho BG, Nicoletto SCS, Cordoni JL. Trabalho gerencial em Unidades Básicas de Saúde de municípios de pequeno porte no Paraná, Brasil. Interface (Botucatu) [Internet]. 2016 [citado 2018 fev. 23];20(58):573-84. Disponível em: http://www.scielo.br/pdf/icse/ v20n58/1807-5762-icse-1807-576220150065.pdf

17. Mosser G, Begun JW. Compreendendo o trabalho em equipe na saúde. Porto Alegre: Artmed; 2015.

18. Cunha P, Meneses R, Oliveira MC. Gestão de conflitos na área da saúde: uma proposta de reflexão. Arq Med [Internet]. 2013 [citado 2018 Jan 09];27(3):132-4. Disponível em: http://www.scielo.mec.pt/pdf/am/v27n3/v27n3a06.pdf

19. Gomes LB, Merhy EE. Subjetividade, espiritualidade, gestão e Estado na Educação Popular em Saúde: um debate a partir da obra de Eymard Mourão Vasconcelos. Interface (Botucatu) [Internet]. 2014 [citado 2018 jan. 16];18(Suppl 2):1269-81. Available from: http://www.scielo. br/pdf/icse/v18s2/1807-5762-icse-18-s2-1269.pdf 